\title{
Using Crumb Rubber from Waste Tires to Reduce Road Traffic Noise
}

\author{
Olga Frolova ${ }^{1,}{ }^{*}$, Brigita Salaiová ${ }^{1}$, Tomáš Olexa $^{1}$, and Ján Mandula ${ }^{1}$ \\ ${ }^{1}$ Technical University of Kosice, 04200 Vysokoskolska 4, Kosice, Slovakia
}

\begin{abstract}
The results of measurements of sound pressure levels on an experimental road section (road pavement with addition of crumb rubber from waste tires) in Mala Ida village (Kosice region, Slovakia) and on a road with stone mastic asphalt in Haniska village (Presov region, Slovakia) are presented in the paper. The results obtained using statistical pass-by methods were compared and they confirmed that road surface with addition of crumb rubber from waste tires produced quieter pavement than stone mastic asphalt road pavement alone.
\end{abstract}

\section{Introduction}

In general noise has a negative influence on life quality in urban areas located in noisy environments. People who live in these areas suffer from various problems [1-5]. However, it is not so easy to evaluate the effects of noise on people [6-9]. The largest contribution to road traffic noise is the tire/road noise at speeds above $50 \mathrm{~km} / \mathrm{h}[7]$.

The following experimental findings were obtained concerning the relationship between the noise and road surface [7]:

1. Surface texture with characteristic particle length greater than $20 \mathrm{~mm}$ tends to increase noise.

2. Surface texture with characteristic particle length less than $10 \mathrm{~mm}$ tends to reduce noise.

3. Porosity of the pavement tends to reduce aerodynamic noise above $1500 \mathrm{~Hz}$.

4. An elastic pavement surface reduces noise and other mechanical noise sources.

5. Better results tend to be obtained for negative texture (below the surface) than for positive texture (sticking out of the surface).

Nowadays in road construction porous materials absorbing noise (for example, PA Porous asphalt pavement) are used, but this road cover type is difficult from the maintenance and cleaning points of view, especially in winter when the pores are clogged with dirt and snow and the surface does not serve as acoustic cover anymore [10]. For this reason asphalt mixtures with the addition of crumb rubber from waste tires with better porosity attract much attention. These mixtures have good slip resistance and acoustic properties [11].

* Corresponding author: olga.frolova@tuke.sk 
For the correct assessment of the impact of road noise it is necessary to measure the noise correctly [12]. The most frequently used ways of measuring tire/road noise are the Close Proximity (CPX) method and the Statistical Pass-By (SPB) method [7, 13-16]. Both methods give accurate results.

The SPB method is used for the measurement of sound pressure levels from common traffic at a speed that is approximately constant. The speed and type of the vehicles passing the roadside microphone are recorded. Vehicles are classified in one of three categories (cars (category 1), dual-axle heavy vehicles (category $2 \mathrm{a}$ ) and multi-axle heavy vehicles (category $2 b$ ) and one of three reference speeds is chosen according to the average operating speed of the road. A minimum of 100 vehicles in the category "cars" and 80 vehicles in the categories "dual-axle heavy vehicles" and "multi-axle heavy vehicles" have to be included in the measurement. Statistics are used to determine the noise levels for the road at different speeds and vehicle categories [7, 13, 17-19].

The Close Proximity Method (CPX) is based on a test in which the tire rolls over the road or the test track surface with measuring microphones located close to the tire surface. In the CPX method, the average A-weighted sound pressure levels emitted by two or four specified reference tires [20] are measured over an arbitrary or a specified road distance, together with the vehicle testing speed. The data are collected by at least two microphones, located close to the tires. For this purpose, a special test vehicle is constructed. The CPX method technology and results of measurements road traffic noise using CPX method are reported in $[7,11,13,16,21-23]$. The measurements using the CPX method are performed in accordance with [24].

Noise level measurements on a road section with crumb rubber additive presented in this paper were carried out using the SPB (Statistical Pass-By) method [17] because it can eliminate the variability of noise emissions from different vehicles within each type and noise measurements near the receptors along a roadway and it is more representative of actual traffic conditions..

\section{Experimental}

\subsection{Road section with asphalt-rubber mixture.}

Asphalt-rubber mixture is a solution to many problems with waste tires. The results of laboratory tests prove that mixtures with rubber have comparable or better properties than traditional asphalt mixes. The design of the mixture has a major influence on its properties. According to test results presented in [25], the optimal amount of rubber particles is $1.2 \%$ of aggregate weight. The rubber content should be chosen taking into account the aggregate and binder content. The studied asphalt mixture was developed within the project "NFP 26220220051 Development of progressive technologies for utilization of selected waste materials in road construction engineering, supported by the European Union structural funds" at the Department of Geotechnics and Traffic Engineering, Technical University of Kosice. When the asphalt mixture went through laboratory testing an experimental road section was constructed. The original surface layer of this road was replaced with asphalt mixture with addition of crumb rubber. Additive Addibit L300 was used in this pavement because it improves the affinity between aggregate and bitumen. Crumb rubber from waste tires was supplied by the company V.O.D.S. a.s., and this product fulfils all current environmental and health standards in the EU. The experimental section of road is $200 \mathrm{~m}$ long and the surface layer is $40 \mathrm{~mm}$ thick. The weather during the laying process was 
acceptable with air temperatures from $15^{\circ} \mathrm{C}$ to $25^{\circ} \mathrm{C}$. The temperature of the mixture after output from the plant was $160^{\circ} \mathrm{C}$. The laying and compaction were done one hour after mixing and the temperature of the pavement was over $135^{\circ} \mathrm{C}$. These processes were the same as for ordinary mixtures. Views on road section with addition of crumb rubber are shown in Fig. 1.
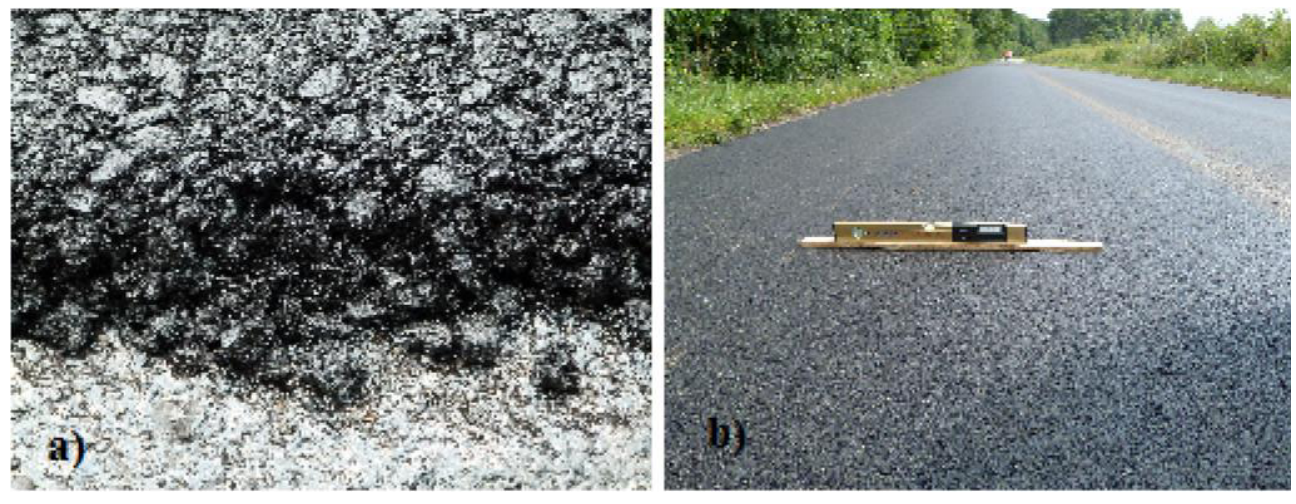

Fig. 1 Road section with addition of crumb rubber a) view of the mixture; b) view of the experimental road section.

\subsection{Noise measurements}

The measurements were carried out on the experimental road section consisting of asphalt concrete with added crumb rubber (Road section 1), and reference road section with stone mastic asphalt (SMA) (Road section 2).

Road section 1: Kosice region, Mala Ida village, road II/548, with width $7.5 \mathrm{~m}$, reference speed $90 \mathrm{~km} / \mathrm{h}$, average value of road speed $71.14 \mathrm{~km} / \mathrm{h}$, and according to [17] the road has "a medium speed" category. Road surface material - AC 11 (Asphalt Concrete) with $1.2 \%$ crumb rubber (CR) from waste tires.

Road section 2: Presov region, Haniska village, road E50 connecting to highway D1. Reference speed $80 \mathrm{~km} / \mathrm{h}$, average value of road speed $74 \mathrm{~km} / \mathrm{h}$, and according to [17] the road has ,a medium speed" category. Road surface material - SMA 11.

During the measurements the following experimental equipment was used:

Traffic Detection Device Sierzega SR4 to measure the instantaneous velocity, time of passage and the length of the vehicle. The device was located $1 \mathrm{~m}$ from the road surface at an angle of $30^{\circ}$ from the direction parallel with the axis of the road. The measurement uncertainty for speed is $\pm 3 \%$, for the length of vehicle $\pm 20 \%$, and for time $\quad \pm 0.2 \mathrm{~s}$. The speed should be measured at the time instant when the vehicle passes the microphone [17].

Sound level meter type 2250 with frequency analysis module BZ 7223 was used. This is a sound analyzer with class 1 precision according to EN 61672 with a 120 dB dynamic range without switching. Prepolarized 1/2" free-field microphone of type 4189 was used.

\section{Results and discussion}

To evaluate the noise reduction effect of a specific pavement, it is necessary to carry out reliable acoustical measurements. For our measurements the SPB (Statistical Pass-By) method was chosen. The SPB method takes into account all aspects of traffic noise at the sideline of the highway, including engine, exhaust and aerodynamic noise. The method also 
detects variations in noise from vehicles of the same type. In the SPB method random sampling of vehicles is used. The details of the SPB method are specified in ISO 11819-1 [17].

During the measurements the maximum sound pressure level was recorded when the vehicle passed closest to the microphone, and the speed of each vehicle and its length were measured as well. The next step of data processing was data normalization. The values of maximum sound level of the vehicle and the decimal logarithm of the vehicle speed were obtained. Linear regression analysis was then used for data processing. The least-squares method was used for the parameters of regression line calculation for each category of vehicle. The coordinate of the sound pressure level on the regression line for each vehicle category at the equivalent reference speed is the sound pressure level of the vehicle $\mathrm{L}_{\mathrm{veh}}$. For this reason three values of $\mathrm{L}_{\mathrm{veh}}$ were obtained at the specific location: for passenger cars, for two-axle heavy vehicles and for multi-axle heavy vehicles [17]. The average Aweighting sound pressure levels are determined separately for each category (see in Fig. 2). By using weighting factors that can be adapted to the traffic flow composition, an SPBI (Statistical Pass-By Index) ranking of surfaces suitable to the specific application can be generated (SPBI see in Fig. 3).

SPBI (Statistical Pass-By Index) is not an equivalent sound pressure level, but it can be used to describe the relative impact of the road surface of these levels. SPBI was calculated in accordance with [17].

$$
S P B I=10 \lg \left[W_{1} \times 10^{L_{1} / 10}+W_{2 a}\left(v_{1} / v_{2 a}\right) \times 10^{L_{2 a} / 10}+W_{2 b}\left(v_{1} / v_{2 b}\right) \times 10^{L_{2 b} / 10}\right] d B
$$

Where SPBI is Statistical Pass-By Index for normalized composition light and heavy vehicles, $\mathrm{dB} ; L_{1}, L_{2 a}, L_{2 b}$ are acoustic pressure levels for vehicle category $1,2 \mathrm{a}$ and $2 \mathrm{~b}$ according to [17]; $W_{1}, W_{2 a}, W_{2 b}$ are weighting factors which correspond to the probably proportion of vehicles categories in automobile traffic; $v_{1}, v_{2 a}, v_{2 b}$ are reference speeds of single vehicles category, according to [17].

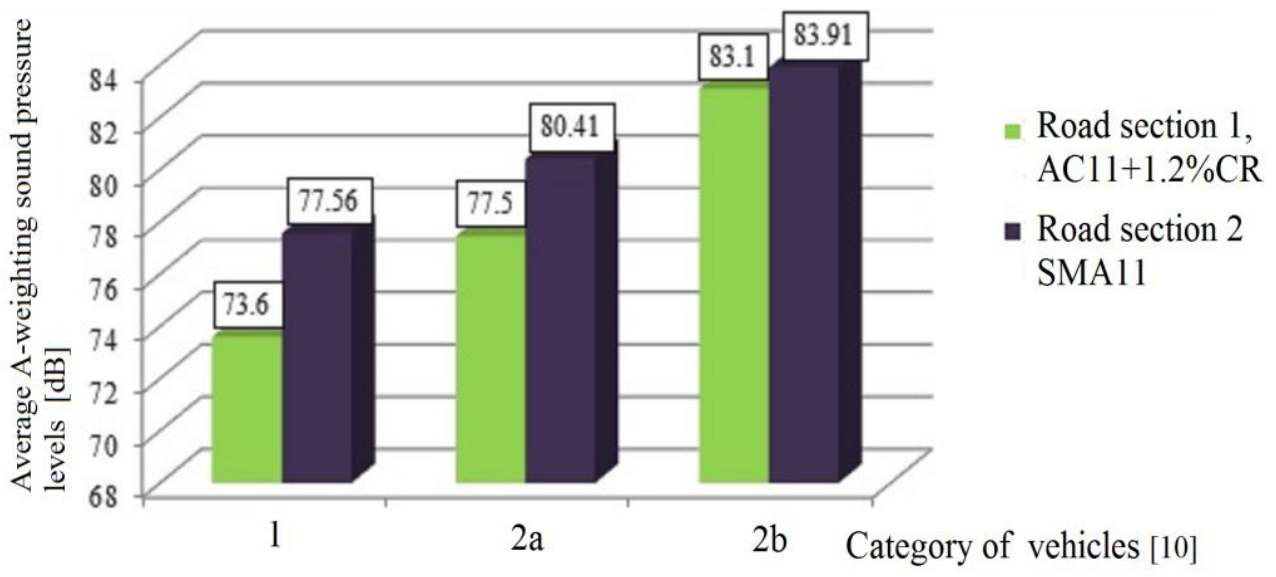

Fig. 2. Average A-weighting sound pressure levels for 2 road sections. 


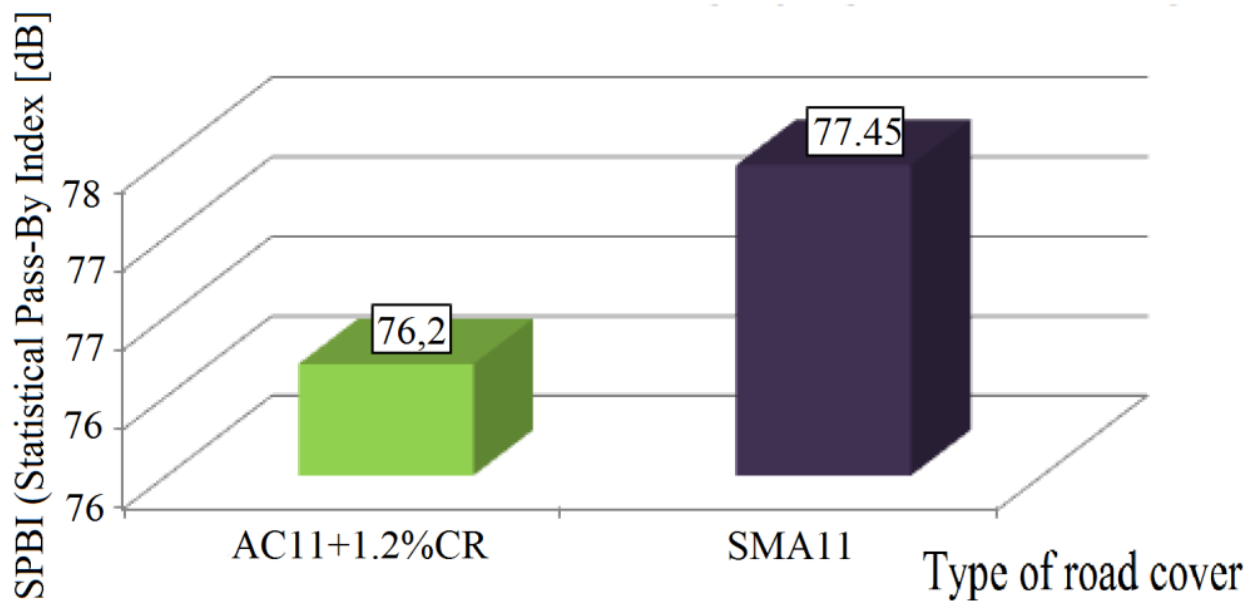

Fig. 3. Comparison of SPBI for 2 types of road cover, [dB].

Better acoustic properties for all three categories of vehicles (passenger cars, two-axle heavy vehicles and multi-axle heavy vehicles) were confirmed for the AC 11 surface with addition of $1.2 \%$ crumb rubber from waste tires, as can be deduced from the comparison of the average sound pressure levels (Fig. 3). The SPBI takes into account the impact of the vehicle category, reference speed of the road and weighting factors. The SPBI values also show that AC $11+1.2 \%$ CR cover has better acoustic properties (SPBI was $76.2 \mathrm{~dB}$ ) versus SMA 11 cover (SPBI was $77.45 \mathrm{~dB}$ ).

\section{Conclusions}

Detection of the acoustic situation is an important factor for the assessment of environment quality. The results presented show that it is possible to produce a quieter road pavement that is safe, durable and economical using current technology. Our measurements of acoustic properties of road surfaces carried out using the SPB method on two road sections in the Kosice and Presov regions confirmed that sound pressure levels for the road surface with addition of crumb rubber from waste tires revealed that it was a quieter surface than SMA road pavement. The comparison of sound pressure levels was carried out using the average sound pressure level and SPBI values.

\section{Acknowledgements}

The contribution was incurred within Centre of the cooperation, supported by the Agency for research and development under contract no. SUSPP-0013-09 by businesses subjects Inžinierske stavby and EUROVIA SK.

The research has been carried out within the project NFP 26220220051 Development of progressive technologies for utilization of selected waste materials in road construction engineering, supported by the European Union Structural funds.

\section{References}

1. G. H. Pandya, International Journal of Environmental Studies, 60(6), 595-602 (2003) 
2. N. Riedel, , H. Köckler, , J. Scheiner, K.Berger, Journal of Environmental Planning and Management (2013)

3. Racioppi, F., Eriksson. L., Tingvall, C., Villaveces, A. Preventing road traffic injury: a public health perspective for Europe (2004) World health organization, $97 \mathrm{p}$.

4. V. P. Podolsky, Vozdejstvie shuma, vibracij i elektromagnitnogo izluchenija na okruzajushchuju sredu v zone vlijanija avtodorog (Voronezh State University of Architecture and Civil Engineering, Voronezh, 1996)

5. V.P. Podolsky, , V. G. Artyukov, V. S. Turbin, , A. N. Kanishchev, Avtotransportnoje zagrjaznenije pridorozhnich territorij (Voronezh University Press, Voronezh, 1999)

6. C. Smetana, Hluk a vibrace. Měrení a hodnocení (Sdělovací technika 1999)

7. R. Bernhard, R. L. WaysonFinal Research Report Number: SQDH 2005-1. Purdue University, (2005)

8. J. Alberola, I. H. Flindell, A. J. Bullmore, Applied Acoustic, 66, 1180-1195 (2005)

9. B. Salaiová, J. Mandula, M. Koval'aková, Hluk $z$ dopravy (Technical university of Kosice, Civil Engineering faculty, 2010)

10. I. Gschwendt, Konštrukcie a ich dimenzovanie (Jaga Group, 1999)

11. J. Kudrna, , O. Dašek, Vysoké učení technické v Brně, (2009)

12. M. Hassall, M Zaveri, Acoustic noise measurement: Fifth edition (1988)

13. I. D.Hanson, S. R. James, C. NeSmith, Tire pavement noise study (Auburn University0 Auburn, 2004)

14. S. Pugh, D. Claughton, F. Kamst, Acoustics (2008)

15. V. Křrivánek, K. Effenberger, Transactions on transport sciences, 3, 109-116 (2014)

16. L. Nekula, V. Křivánek, Silnice mosty, 3, 19-23 (2015)

17. STN EN ISO 11819-1:1997. Acoustics. Measurement of the influence of road surfaces on traffic noise. Part 1: Statistical Pass-By method.

18. M. Haider, G. Descornet, Noise classification methods for urban road surfaces Classification Methodology. Silence. Integrated project - contract N. 516288(2006)

19. J. M. Brennan, A. M. Kavanahgt, N. J. Sheahan, International Journal of Pavement Engineering, 2(2), 121-134 (2007)

20. P. Morgan, U. Sandberg, G. Blokland, INTER-NOISE 2009, 1, 462-470 (2009)

21. J. Kachtík, O. Dašek, P. Coufalík, Silnice železnice, 4, 74-79 (2013)

22. V. Křivánek, R. Cholava, IV Czech-Slovak Scientific Conference „Transport, Health and Environment", 213-239 (2010)

23. J. Smutný, L. Pazdera, J. Gottvaldová, Silnice-Železnice, 5, (2011)

24. ISO/CD 11819-2 Acoustics - Measurement of the influence of road surfaces on traffic noise - Part 2: The close-proximity method (2000)

25. T. Olexa, P. Orolin, J. Mandula, B. Salaiová, Situation in ecologically polluted regions of Slovakia and Central Europe: 23 scientific symposium with international participation, 91-94 (2014) 